\title{
Evaluation of Self Efficacy Based Nurse Performance Appraisal Instrument Development at Lavalette Malang Hospital
}

\author{
Rahayu Tri Nuritasari ${ }^{1}$, Rizki Fitriyasari ${ }^{1 *}$, M. Hasinuddin ${ }^{2}$ \\ ${ }^{I}$ Universitas Airlangga Surabaya, Indonesia \\ ${ }^{2}$ STIKes Ngudia Husada Madura, Indonesia \\ * rizzki-f-p-k@fkp.unair.ac.id
}

\begin{abstract}
Performance appraisal is problematic if it does not describe competence. The purpose of this study was to develop a nurse performance appraisal instrument following standards by integrating the dimensions of self-efficacy in behavioral assessment. Design of the research was explorative descriptive research with a research and development approach. The population in this study were all nurses of unit Lavalette Hospital Malang. The sample was 110 nurses obtained by cluster sampling based on inclusion criteria. The variable in this study is performance evaluation based on self-efficacy. Researchers use a questionnaire as an instrument for evaluation and study documentation. Data were then analyzed using descriptive analysis. Development of instruments based on Focus Group Discussion and expert discussion. The result show evaluation of components in the nurse performance appraisal system when viewed according to its indicators, most are rated in the sufficient category. Assessment criteria and performance records get enough categories in the highest percentage of $76.4 \%$, evaluation of the standard components of work behavior assessment is mostly not done with percentages above $20 \%$, performance appraisal instruments do not describe the performance of nurses and do not conform to standards. It is necessary to develop an appraisal of performance instruments that conform to standards with behavioral assessments that are in line with nurse performance, to increase satisfaction and continuity of nursing care services.
\end{abstract}

Keywords : Nurse Performance, Performance Assessment, Self-efficacy, Work Behavior 


\section{STRADA Jurnal Ilmiah Kesehatan}

DOI: $10.30994 /$ sjik.v9i2.349

ISSN: 2252-3847 (print); 2614-350X (online)

Vol.9 No.2 November 2020 Page.644-655

\section{BACKGROUND}

The performance appraisal process is an important stage in HR management (Apak, Gümü, Öner, \& Gülnihal, 2016). The four problems in the nurse's performance appraisal system are contextual issues (disharmony between nurses' standards and duties), performance appraisal structure (subjective appraisals), the appraisal process (lack of supervision from managers, unfair assessments and the unsustainability of the assessments performed) and assessment results namely inappropriate feedback (Nikpeyma, Saeedi, Azargashb, \& Majd, 2014).

Performance assessment instruments are problematic if not representative describe the competency (Kalb et al., 2006) Assessment indicators used are less pronounced (Aneshansley et al., 2008), the instrument used is always the same from year to year (Vafaee Najar, Pooya, Alizadeh Zoeram, \& Emrouznejad, 2018) eligibility for use is still lacking (Jeffs et al., 2014) and the standard mismatch in performance with the duties of nurses (Nikpeyma et al., 2014). Performance assessment will not increase the working productivity if it is inappropriate, inaccurate and not acceptable to the user due to an error in the evaluation content, errors in the evaluation process, disharmony between the employee's needs and the purpose of judgment or the existence of a clear dimension of performance (Kahya, 2018).

Research Chairina (2019) said that the standardized assessment makes input for management to be able to know how the development and strategies will be taken for the management of human resources needed by the hospital. Through performance assessment, management can make internal improvement that is one of them through the development of human Resources (Sabitah \& Susilo, 2017). The success of the hospital in improving performance is highly dependent on the quality of the resulting human resources. Performance appraisals can help employers to give their employees the opportunity to pursue careers and keep working in the hospital motivated and as a feedback from the results of the performance given (Nikpeyma et al., 2014).

The results of the interview conducted on 12 September 2019, the head of the nursing committee said that the absence of instruments as a measuring instrument to evaluate the performance of nurses. During this time the assessment tools used are assessment tools for general employee performance conducted once a year. In addition, the performance assessment conducted so far is with a scheduled supervision, seeing attendance or attendance, and more to the performance assessment of the new nurse who completed the orientation. Based on the results of the interview with the head of space on 12 September 2019, the performance assessment of nurses in the hospital was done. The performance assessment implementation for the task description is done in accordance with the nurse's career level, but the reward received by the nurse has not been in accordance with clinical nurse career level determination.

Many leaders and managers are less concerned about the importance of career development for the hospital itself. The development of career developments conducted by the hospital can improve the ability of individual work in achieving the desired career. Providing career opportunities and the advancement of Nurse careers, the ability of nurses in individual performance will improve hospital performance. Companies that do not pay attention to the sustainability of their employees ' careers can cause employee dissatisfaction and intention to leave from the company (De Simone, Planta, \& Cicotto, 2018). Human resources that are competent and have good skill and performance have a high self efficacy potentially to be competitive in their performance, have satisfaction on the outcome of the work, and have the achievement of work (Mangi, Ter Goon, \& Yako, 


\section{STRADA Jurnal Ilmiah Kesehatan}

DOI: $10.30994 /$ sjik.v9i2.349

ISSN: 2252-3847 (print); 2614-350X (online)

Vol.9 No.2 November 2020 Page.644-655

2019). Self efficacy is an individual factor that affects performance. Self efficacy mediated by individual belief about self-ability to successfully perform tasks in order to obtain desired results (Bandura, 2006)

The role of self efficacy towards performance is backed by Carter (2018) research results suggesting that self efficacy can significantly predict the level of achievement of individual work. Self efficacy is related to job satisfaction where if a person has a high self-efficacy then it tends to succeed in his duties and increase the satisfaction of what he works. High performance emerged when the individual was satisfied with the results of his duties, influenced the role of self efficacy and mastery of the task (Kurniawan, Hariyati, \& Afifah, 2019).

In the advancement of Nurse careers, hospital management should be able to see and know the self efficacy every nurse to support the organizational goals in the future.

\section{MATERIALS AND METHODS}

The research design used is the explorative descriptive research using the Research and Development $(R \& D)$ approach. Data Collection is conducted from March 2, 2020 until May 28, 2020 using cluster sampling technique. This Research was conducted at Lavalette Hospital Malang. The population in this study was all the implementing Nurses in Malang's Lavalette hospital amounting to 155 respondents. The population for the Focus Group Discussion (FGD) is the management of the hospital, consisting of management of the field of nursing, chairman of the Nursing Committee, inpatient and outpatient coordinators, and head of the chamber and implementing nurses. The sample was used in this study as many as 110 implementing nurses, 9 participant representatives who were participants from 9 rooms, and 13 FGD participants with the hospital's managerial ranks. The criteria for nurse inclusion in this study were primary nurses and associate nurses who had completed the Preceptorship series (no longer in mentoring in conducting actions). The exclusion criteria of the study are the nurses who on delivery leave or big leave and Nurses who are in a further study (in a study permit). The variables in this research are self-efficacy. based nurse performance assessment. How to collect data with evaluation questionnaire and observation of the instrument performance assessments that have been used in addition, data or information obtained from FGD activities with implementing nurses, Head of space and managerial ranks. This Study has passed the examination of the Faculty of Health Research Ethics Commission of Airlangga University with a Code of ethics 1923-KEPK.

\section{RESULTS}

Table 1. Evaluation of the performance assessment system of the implementing NURSE at hospital Lavalette Malang $(\mathrm{n}=110)$

\begin{tabular}{llcccc}
\hline \multirow{2}{*}{ No } & Parameters & \multicolumn{4}{c}{ Category } \\
\cline { 3 - 5 } & & Good & Enough & Less & Total \\
\hline $\mathbf{1}$ & Scoring criteria & $12(10.9 \%)$ & $84(76.4 \%)$ & $14(12.7 \%)$ & $110(100 \%)$ \\
\hline $\mathbf{2}$ & Size of performance values & $28(25.5 \%)$ & $68(61.8 \%)$ & $14(12.7 \%)$ & $110(100 \%)$ \\
\hline $\mathbf{3}$ & Performance Scoring System & $29(26.4 \%)$ & $65(59.1 \%)$ & $16(14.5 \%)$ & $110(100 \%)$ \\
\hline $\mathbf{4}$ & Valuation Feedback & $27(24.5 \%)$ & $68(61.8 \%)$ & $15(13.6 \%)$ & $110(100 \%)$ \\
\hline $\mathbf{5}$ & Performance Notes & $10(9.1 \%)$ & $84(76.4 \%)$ & $16(14.5 \%)$ & $110(100 \%)$ \\
\hline $\mathbf{6}$ & Job Achievement & $32(29.1 \%)$ & $70(63.6 \%)$ & $8(7.3 \%)$ & $110(100 \%)$ \\
\hline $\mathbf{7}$ & Objectivity assessment & $37(33.6 \%)$ & $66(60 \%)$ & $7(6.4 \%)$ & $110(100 \%)$ \\
\hline $\mathbf{8}$ & Satisfaction of the scoring system & $47(42.7 \%)$ & $54(49.1 \%)$ & $9(8.2 \%)$ & $110(100 \%)$ \\
\hline $\mathbf{9}$ & Satisfaction on top judgment & $32(29.1 \%)$ & $59(53.6 \%)$ & $19(17.3 \%)$ & $110(100 \%)$ \\
\hline
\end{tabular}




\section{STRADA Jurnal Ilmiah Kesehatan}

DOI: $10.30994 /$ sjik.v9i2.349

ISSN: 2252-3847 (print); 2614-350X (online)

Vol.9 No.2 November 2020 Page.644-655

\begin{tabular}{llcccc}
\hline \multirow{2}{*}{ No } & Parameters & \multicolumn{3}{c}{ Category } \\
\cline { 3 - 5 } & & Good & Enough & Less & Total \\
\hline $\mathbf{1 0}$ & Superior knowledge of actual & $43(39.1 \%)$ & $66(60 \%)$ & $1(0.9 \%)$ & $110(100 \%)$ \\
& performance & $35(31.8 \%)$ & $68(61.8 \%)$ & $7(6.4 \%)$ & $110(100 \%)$ \\
\hline $\mathbf{1 1}$ & Satisfaction of feedback & $35 \%$ &
\end{tabular}

Table 1 explains the evaluation of components in a nurse's performance assessment system if viewed according to the indicator is largely assessed in sufficient categories. Satisfaction with the most scoring system gets the percentage of judgment good. Scoring criteria and performance records get the category sufficiently in the highest percentage $(76.4 \%)$ Comparison of other assessment components.

Table 2. Component evaluation results in standard Work behavior $(\mathrm{n}=110)$

\begin{tabular}{llcccc}
\hline \multirow{2}{*}{ No } & \multicolumn{1}{c}{ Indicators } & \multicolumn{4}{c}{ Category } \\
\cline { 3 - 6 } & & Good & Enough & Less & Total \\
\hline $\mathbf{1}$ & Service Orientation & $21(19.1 \%)$ & $47(42.7 \%)$ & $42(38.2 \%)$ & $110(100 \%)$ \\
\hline $\mathbf{2}$ & Integrity & $37(33.6 \%)$ & $54(49.1 \%)$ & $19(17.3 \%)$ & $110(100 \%)$ \\
\hline $\mathbf{3}$ & Commitment & $34(30.9 \%)$ & $30(27.3 \%)$ & $46(41.8 \%)$ & $110(100 \%)$ \\
\hline $\mathbf{4}$ & Discipline & $78(70.9 \%)$ & $29(26.4 \%)$ & $3(2.7 \%)$ & $110(100 \%)$ \\
\hline $\mathbf{5}$ & Cooperation & $35(31.8 \%)$ & $25(22.7 \%)$ & $50(45.5 \%)$ & $110(100 \%)$ \\
\hline $\mathbf{6}$ & Leadership & $12(10.9 \%)$ & $37(33.6 \%)$ & $61(55.5 \%)$ & $110(100 \%)$ \\
\hline
\end{tabular}

Table 2 explains the evaluation of components in the standard of work behavior when viewed according to the indicator is largely not done with a percentage above $20 \%$. The working behavior component used at hospital Lavalette Malang has not been referring to the standard working behavior of Permenkes number 1year 2019.

Table 3. Results of observation of conformity instruments performance assessment of nurses with Permenkes

\begin{tabular}{|c|c|c|c|c|}
\hline \multirow[t]{2}{*}{ No } & \multirow[t]{2}{*}{ Components } & \multicolumn{2}{|c|}{ Format } & \multirow[t]{2}{*}{ Description } \\
\hline & & Lavalette HOSPITAL & Permenkes & \\
\hline 1 & $\begin{array}{l}\text { Instrument } \\
\text { title }\end{array}$ & Performance appraisal & Work Achievement Form & Appropriate \\
\hline \multirow[t]{3}{*}{2} & \multirow{3}{*}{$\begin{array}{l}\text { Identity } \\
\text { assessment }\end{array}$} & Employees assessed & Votes & Appropriate \\
\hline & & $\begin{array}{l}\text { Officials of the } \\
\text { assessment }\end{array}$ & Officials of the assessment & Appropriate \\
\hline & & $\begin{array}{l}\text { Chief Assessment } \\
\text { Officer }\end{array}$ & Officials Supervisor & Appropriate \\
\hline \multirow[t]{3}{*}{3} & \multirow[t]{3}{*}{$\begin{array}{l}\text { Evaluation } \\
\text { Component }\end{array}$} & Work results & $\begin{array}{l}\text { Employee Performance } \\
\text { Objectives }\end{array}$ & Appropriate \\
\hline & & $\begin{array}{ll}\text { Properties/Behaviors } \\
\text { a. } & \text { Honesty } \\
\text { b. Example } \\
\text { c. Loyalty } \\
\text { d. Discipline } \\
\text { e. } & \text { Creativity } \\
\text { f. The Spirit of work } \\
\text { g. } & \text { Responsibility }\end{array}$ & $\begin{array}{ll}\text { Work behavior } \\
\text { a. } & \text { Service Orientation } \\
\text { b. } & \text { Integrity } \\
\text { c. } & \text { Commitment } \\
\text { d. } & \text { Discipline } \\
\text { e. } & \text { Cooperation } \\
\text { f. } & \text { Leadership }\end{array}$ & Inappropriate \\
\hline & & Technical capabilities & & Not appropriate \\
\hline \multirow[t]{4}{*}{4} & \multirow[t]{4}{*}{ Legality } & $\begin{array}{l}\text { Performance } \\
\text { Assessment Conclusion }\end{array}$ & $\begin{array}{l}\text { Objection from being } \\
\text { assessed }\end{array}$ & Not appropriate \\
\hline & & & $\begin{array}{l}\text { An assessment officer's } \\
\text { response to objections }\end{array}$ & Not appropriate \\
\hline & & & $\begin{array}{l}\text { Decision of an assessment } \\
\text { officer on objection }\end{array}$ & Not appropriate \\
\hline & & & Recommendations & Not appropriate \\
\hline
\end{tabular}




\section{STRADA Jurnal Ilmiah Kesehatan}

DOI: $10.30994 /$ sjik.v9i2.349

ISSN: 2252-3847 (print); 2614-350X (online)

Vol.9 No.2 November 2020 Page.644-655

\begin{tabular}{lll}
$\begin{array}{l}\text { The employee's TTD } \\
\text { assessed }\end{array}$ & TTD assessed & Appropriate \\
\hline $\begin{array}{l}\text { TTD Assessment } \\
\text { Officers }\end{array}$ & TTD Assessment Officers & Appropriate \\
\hline $\begin{array}{l}\text { TTD Supervisor } \\
\text { Officials }\end{array}$ & TTD Supervisor Officials & Appropriate \\
\hline
\end{tabular}

Table 3 describes the suitability of the instrument format of the Nurse performance assessment used in hospital Lavalette Malang with Permenkes number 1 Year 2019 obtained results of some components that are already in accordance with the standard. Majority assessment and endorsement components are not appropriate.

Table 4. FGD results Development of the Nurse performance assessment Self-Efficacy

\begin{tabular}{|c|c|c|c|c|}
\hline No & Strategic issues & Cause & FGD Results & Research study \\
\hline 1 & $\begin{array}{l}\text { The content and } \\
\text { indicators of nurse } \\
\text { performance } \\
\text { assessment } \\
\text { unclear. }\end{array}$ & $\begin{array}{l}\text { 1. The instrument } \\
\text { used for the } \\
\text { performance } \\
\text { assessment of } \\
\text { nurses has not } \\
\text { been effective in } \\
\text { assessing the } \\
\text { nurse's } \\
\text { performance } \\
\text { 2. RS has not set a } \\
\text { standard for a } \\
\text { good } \\
\text { performance/achi } \\
\text { evement nurse. } \\
\text { 3. The new } \\
\text { assessment } \\
\text { results are limited } \\
\text { in number, RS } \\
\text { does not yet have } \\
\text { any reward- } \\
\text { related policies } \\
\text { or awards for } \\
\text { well-performing } \\
\text { nurses. }\end{array}$ & 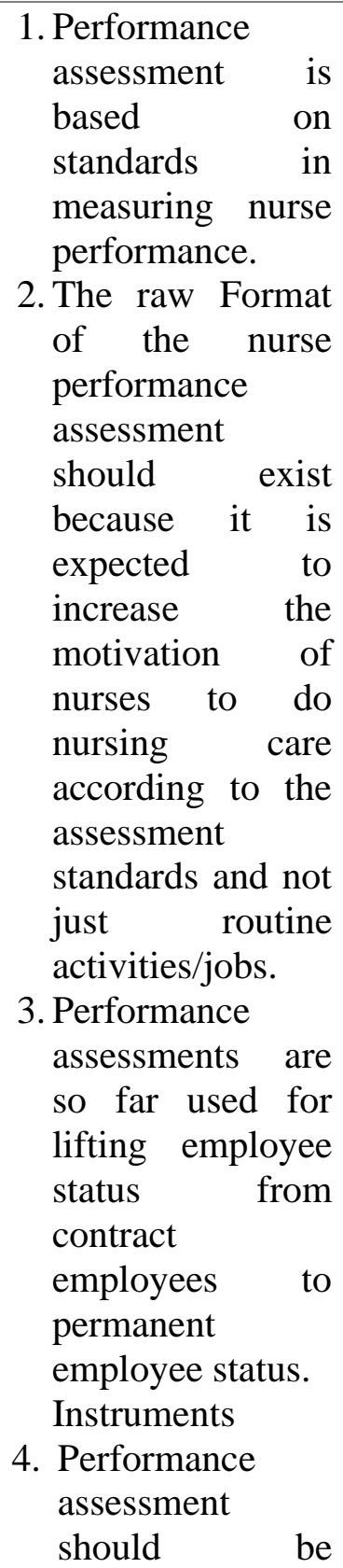 & $\begin{array}{l}\text { 1. The content and } \\
\text { indicators of the } \\
\text { performance } \\
\text { assessment } \\
\text { Instrument used } \\
\text { in the RS are not } \\
\text { yet standard. } \\
\text { 2. The preparation } \\
\text { of new } \\
\text { instruments in } \\
\text { assessing the } \\
\text { special } \\
\text { performance of } \\
\text { nurses. } \\
\text { 3. The award is } \\
\text { given in } \\
\text { accordance with } \\
\text { the results of } \\
\text { achievement so } \\
\text { that it needs to be } \\
\text { rewarded for the } \\
\text { work } \\
\text { performance of } \\
\text { nurses. }\end{array}$ \\
\hline
\end{tabular}




\section{STRADA Jurnal Ilmiah Kesehatan}

DOI: $10.30994 /$ sjik.v9i2.349

ISSN: 2252-3847 (print); 2614-350X (online)

Vol.9 No.2 November 2020 Page.644-655

\begin{tabular}{|c|c|c|c|c|}
\hline No & Strategic issues & Cause & FGD Results & Research study \\
\hline & & & $\begin{array}{l}\text { followed by a } \\
\text { reward feedback } \\
\text { or response } \\
\text { from the hospital } \\
\text { as an effort to } \\
\text { improve the } \\
\text { motivation and } \\
\text { performance of } \\
\text { nurses. }\end{array}$ & \\
\hline 2 & $\begin{array}{l}\text { Assessment of work } \\
\text { behavior used does } \\
\text { not refer to } \\
\text { Permenkes number } \\
1 \text { year } 2019\end{array}$ & $\begin{array}{l}\text { 1. The assessment } \\
\text { of the behavior } \\
\text { used by the } \\
\text { current RS is a } \\
\text { performance } \\
\text { assessment } \\
\text { employed on all } \\
\text { the employees } \\
\text { and instruments } \\
\text { from the } \\
\text { management } \\
\text { company of } \\
\text { hospital } \\
\text { The Format of } \\
\text { the work } \\
\text { Behavior } \\
\text { assessment that } \\
\text { RS uses does not } \\
\text { refer } \\
\text { Permenkes year } \\
\text { 2019. } \\
\text { The performance } \\
\text { assessment used } \\
\text { has not measured } \\
\text { the confidence in } \\
\text { the nurse in } \\
\text { carrying out the } \\
\text { task. }\end{array}$ & $\begin{array}{l}\text { 1. There needs to be } \\
\text { a clear gauge in } \\
\text { measuring nurse } \\
\text { performance } \\
\text { 2. There must be an } \\
\text { assessment of the } \\
\text { ability and } \\
\text { confidence of } \\
\text { nurses in } \\
\text { providing on } \\
\text { services based on } \\
\text { standards- } \\
\text { compliant } \\
\text { assessments. }\end{array}$ & $\begin{array}{l}\text { 1. The preparation } \\
\text { of new } \\
\text { instruments in } \\
\text { accordance with } \\
\text { the standards in } \\
\text { assessing the } \\
\text { performance of } \\
\text { nurses. } \\
\text { 2. For } \\
\text { preparation of the } \\
\text { SPO and } \\
\text { performance } \\
\text { assessment } \\
\text { technical } \\
\text { indicators. } \\
\text { 3. Compiled } \\
\text { development of } \\
\text { behavioral } \\
\text { assessment which } \\
\text { is integrated } \\
\text { based on self } \\
\text { efficacy Nurses } \\
\text { can be used to } \\
\text { assess confidence } \\
\text { and ability in the } \\
\text { nurse in giving } \\
\text { the waiter }\end{array}$ \\
\hline 3 & $\begin{array}{l}\text { Performance } \\
\text { assessment } \\
\text { instrument formats } \\
\text { not yet compliant }\end{array}$ & $\begin{array}{l}\text { 1. There is no } \\
\text { chance to appeal } \\
\text { if an employee is } \\
\text { objected to the } \\
\text { assessment } \\
\text { outcome. } \\
\text { 2. The results of the } \\
\text { performance } \\
\text { assessment have }\end{array}$ & $\begin{array}{l}\text { 1. Recommendation } \\
\mathrm{s} \text { on assessment } \\
\text { results are } \\
\text { necessary. } \\
\text { 2. Added an } \\
\text { objection column } \\
\text { and } \\
\text { recommendations } \\
\text { in the assessment }\end{array}$ & $\begin{array}{l}\text { 1. Performance } \\
\text { assessment } \\
\text { instruments need } \\
\text { to be revised } \\
\text { according to } \\
\text { Permenkes } \\
\text { standard year } \\
2019 \text {. } \\
\text { 2. The assessment }\end{array}$ \\
\hline
\end{tabular}




\section{STRADA Jurnal Ilmiah Kesehatan}

DOI: $10.30994 /$ sjik.v9i2.349

ISSN: 2252-3847 (print); 2614-350X (online)

Vol.9 No.2 November 2020 Page.644-655

\begin{tabular}{|c|c|c|c|c|}
\hline No & Strategic issues & Cause & FGD Results & Research study \\
\hline & & $\begin{array}{l}\text { not been used in } \\
\text { decision making. } \\
\text { 3. The hospital has } \\
\text { so far not } \\
\text { provided } \\
\text { feedback on the } \\
\text { results of the } \\
\text { performance } \\
\text { assessment. }\end{array}$ & $\begin{array}{l}\text { instrument to be } \\
\text { developed. } \\
\text { 3. Added the } \\
\text { standard category } \\
\text { of performance } \\
\text { assessment on the } \\
\text { instrument. }\end{array}$ & $\begin{array}{l}\text { results can be } \\
\text { used in decision } \\
\text { making for the } \\
\text { performance of } \\
\text { the nurse. }\end{array}$ \\
\hline
\end{tabular}

Table 4 shows the FGD results that have been done that performance assessment Instruments still do not conform to standards, indicators in assessing the performance of nurses are not yet clear and there is no guide in assessing the performance of nurses.

\section{DISCUSSION}

1. Evaluation of performance Assessment system

The assessment criteria and performance records used in assessing performance of the evaluation system are gaining a category with the highest percentage. According to the nurse's valuation criteria and the performance records used at this time do not yet have a clear indicator, is still general and the result of the performance assessment has not been used as a consideration in decision making. The FGD results with nurses regarding assessment criteria and performance records say that the performance assessments used today are not yet effective as they do not depict the competence of the nurses in measuring performance, results from assessments conducted by formalities, follow-up from the new assessment results as a number and have not been followed by other feedback.

Performance assessment effectiveness is very important in the view of nurses (nikpeyma, 2014). According to the Keban (2014) There are several factors that determine the effectiveness of a performance assessment namely: 1) The relevance of the performance assessment criteria; 2) Evaluator's ability to evaluate performance; 3 ) indicators in evaluating performance; 4) Acceptance of the assessed party on the assessment process, and 5) The feedback from the assessment results

Performance assessment effectiveness is very important in the view of nurses (Nikpeyma, 2014). According Keban (2014) There are several factors that determine the effectiveness of a performance assessment namely: 1) The relevance of the performance assessment criteria; 2) Evaluator's ability to evaluate performance; 3) indicators in evaluating performance; 4) Acceptance of the assessed party on the assessment process, and 5) The feedback from the assessment results. The Dusterhoff (2014) study said that feedback from performance assessment results could be used administratively and as one effort in employee development. The results of performance appraisal can be used to determine the awarding of awards (e.g. bonuses), feedback, and make decisions for the placement of promotion positions, as employees ' development efforts can be used in career development, displacement and demotion, means of disciplinary employees, identifying training needs and improving organizational work. Increased performance of nurses in nursing care and fulfilling the purpose of the hospital can be influenced by the satisfaction of the performance assessment system used (Kahya \& Oral, 2018). Nurses who are dissatisfied with the performance 


\section{STRADA Jurnal Ilmiah Kesehatan}

DOI: $10.30994 /$ sjik.v9i2.349

ISSN: 2252-3847 (print); 2614-350X (online)

Vol.9 No.2 November 2020 Page.644-655

assessment system will have an impact on the disharmony between standard nursing and the duties of nurses, lack of motivation on nurses, and bad judgment of the Organization (Gesme \& Wiseman, 2011).

Performance scoring criteria are an important part of assessing the outcome of nurses ' work. The performance scoring criteria used by RS currently have not specifically assessed the competency and duty of nurses. The assessment criteria in accordance with the expectations of the nurse will affect the performance improvement of nurses in providing services that are suitable for the purpose of the hospital. A performance assessment record is an important medium in assessing the outcome of the work shown by the nurse. Records of well-documented performance assessments will be used as managerial consideration materials in the giving of feedback on performance assessment results. The current performance assessment of RS has not been utilized to reward materially, but it should also be given a non-Material award to provide positive feedback on the performance of a good nurse.

2. Evaluation of nurse performance assessment instruments

The evaluation of performance assessment instruments at Lavalette Hospital is assessed based on the standards of title, identity standards, standards of identification and standard of ratification in accordance with PERMENKES year 2019. The result of the evaluation that the performance assessments used in Lavalette hospital currently have several components that have not been in accordance with the standard Permenkes, namely on the content component assessment and endorsement. The assessment content component used by RS currently contains about work outcomes and work behavior. The authentication component used by RS currently only contains the conclusion of the assessment results. Replenishment of the work behavior assessment does not yet have a valuation indicator and guidance in filling the performance assessment instrument.

According to Siagian (2014) Good performance assessment instrument is dependent on four requirements that are direct relation with work, practical, guidance in conducting assessment, and clarity of assessment standards. The use of standardization in performance assessment instruments is important in achieving the success of the organization (Dusterhoff et al., 2014). The performance assessment standards should be based on the assessment of clear work behavior and there must be indicators in the form of task descriptions and evaluation (Apak, Gümüş, Öner, \& Gümüş, 2016). The regulation of the Minister of Health number 1 year 2019 on the guidelines of assessment of employment achievement asserted that the standards of occupational behavior assessment include the aspect of service orientation, integrity, commitment, discipline, cooperation and leadership (Menkes, 2019).

Based on Permenkes number 1 year 2019 performance assessment should contain item objection to the assessment result, response of the appraiser against objection, decision on judgment and recommendation (Menkes, 2019). Research on Catano, Darr, and Campbell (2007) suggests that employees should be given the opportunity to reveal dissatisfaction with the results and process of performance assessment systems performed by superiors. The provision of an opportunity to reveal dissatisfaction with the results of positive impact builds and improves employee performance (Dusterhoff et al., 2014). Recommendations from assessment results are essential as a guideline for employee (Gesme \& Wiseman, 2011). Assessment recommendations can be used to provide information in decision making to nurses such 


\section{STRADA Jurnal Ilmiah Kesehatan}

DOI: $10.30994 /$ sjik.v9i2.349

ISSN: 2252-3847 (print); 2614-350X (online)

Vol.9 No.2 November 2020 Page.644-655

as career development, job arrangement and promotion, workload distribution, and compensation (Dusterhoff et al., 2014).

Appropriate performance assessment instruments and expectations from nurses will improve nursing service continuity. Standardization of performance assessment content must be adhered to the standards set by the government. Regulation of the Minister of Health number 1 of 2019 has set the assessment standards of work achievement that can be used to assess employee performance. The use of noncompliant performance assessment instruments can lead to inconsistency between the standard and duty of the nurse so that it can affect the quality of service provided. Giving the opportunity to feedback from the assessment results is important media in the performance assessment. Employees who do judgment will feel the opportunity to submit an opinion if the assessment result is not in accordance with the actual situation. Recommendations of well-documented performance assessments can be used as managerial considerations in the delivery of feedback on performance assessment results.

3. Self-Efficacy based performance assessment instrument development

The development of the self- efficacy -based Nurse performance assessment Instrument generates a guide and an instrument sheet in the implementation of performance assessments developed in terms of the format and content of the assessment. Instrument Format developed based on the standard number 1year 2019 Permenkes by adding items to the authentication component that objected to the assessment result, the appraiser's response to the objection, decision on judgment and recommendation.

The development of the self efficacy based performance assessment Instrument is an integration of the working behavior assessment standards of the Minister of Health Regulation number 1 year 2019 with a measurement indicator on the self efficacy dimension. In the assessment standards of Permenkes work behavior there are six aspects that are used to assess the performance, namely the Ministry of Service, Integrity, commitment, cooperation and leadership discipline. The assessment in each of these aspects should contain the three aspects that are in the self efficacy dimension adjusted according to the dimensional measurement indicators of the self efficacy. The results of the Sebayang Research (2018) say that Self efficacy can be used as an indicator in assessing behavior. Assessment in measuring behavior based on SelfEfficacy Nurses can be a useful tool in facilitating the application of social-cognitive theories in the field of nursing and even the development of interventions (Lippke, 2017).

Lippke's research (2017) said that three aspects are used to measure behavior based on the self-efficacy dimension. The magnitude aspect is measured by indicators; 1) having an optimistic outlook; 2) conviction of ability in the face of obstacles; 3) Plan a job completion well; 4) have motivation and enthusiasm in the completion of tasks; and 5) Perform tasks in any situation. The generality aspect is measured by indicators; 1) conviction and ability to correct mistakes; 2) Increase task completion efforts; 3 ) not easily give up in completing tasks; 4) have a commitment; and 5) have readiness in completing tasks. The strength aspect is measured by indicators; 1) based on previous experience; 2) addressing situations and conditions in good and positive ways; 3) Support other people's performance in problem solving; and 4) The ability to make good decisions. 


\section{STRADA Jurnal Ilmiah Kesehatan}

DOI: $10.30994 /$ sjik.v9i2.349

Integration of the work behavior assessment contains all the assessment components consisting of 22 indicators. Aspects of assessment of the behavior developed include: Service Orientation (6 indicators), Integrity (3 indicators), commitment (3 indicators), discipline ( 3 indicators), cooperation (3 indicators) and leadership (4 indicators). The indicators of work behavior and dimensions of Self efficacy are modified and adapted to the characteristics of poor Lavalette RS. These indicators are formulated based on the parameters that have been in theory and concept. Service orientation performance indicators are measured by parameters; 1) ability and seriousness in providing nursing care to patients; 2) readiness of nurses when needed by the patient; 3) Effective service based on priority; 4) efficiency and use of facilities in the provision of services; 5) The best initiative in the event of complaints; and 6) Empathy in resolving patient problems. Integrity indicators are measured by parameters; 1) Provision of services in accordance with competence; 2) not easily give up in carrying out duties; 3) responsible and correct errors. Commitment indicators are measured by parameters; 1) prioritizes the patient's interests over personal interests; 2) attachment, pride and taste have nurses to work and RS; 3) Ready to do the work in all conditions. Disciplinary indicators are measured by parameters; 1) timeliness in work; 2) working with the SPO; 3) Compliance with RS regulations. Cooperation indicators are measured by parameters; 1) Resolution of problems with other health teams; 2) The ability to accept the opinions and decisions of others; 3) The establishment of a nurse adaptation in teamwork. Leadership indicators are measured by parameters; 1) actively discussing and communicating opinions; 2) Role models in the working environment; 3) Support and motivate other nurses; 4) The ability to make decisions.

The development of the instrument-based performance assessment of nurse Self efficacy mediated by the belief about the ability to successfully perform tasks in order to get maximum results. Self efficacy based performance assessment Instruments self efficacy can be used to assess the confidence, ability and strength of the nurse in carrying out tasks when faced with any situation. Performance assessment instruments are expected to improve the ability and benchmark of nurses in providing services. The nurse's performance-harvesting instrument requires guidance for better direction, resulting in effective results. The implementation of the nurse's performance assessment is not a difficult thing to do if the SPO is already available and the handbook of filling. It is therefore required to charge guidelines that correspond to the development results.

\section{CONCLUSION}

The conclusion of this research is necessary to develop the performance assessment instrument of nurses with and adjusted to existing research and adjusted to the standards. Assessment of appropriate work behavior is crucial in improving the performance of the nurse in doing its job. Assessment of appropriate work behavior standards and expectations of nurses will be able to improve nursing care continuity. The limitation in this study is to use the population of excepting the implementing nurse in the hospital treatment room without considering the level of nurse workload that will affect the performance assessment process. Advice for further research needs to be developed by the performance assessment instruments of Web-based nurses along with the development of technology and information. 


\section{STRADA Jurnal Ilmiah Kesehatan}

DOI: $10.30994 /$ sjik.v9i2.349

ISSN: 2252-3847 (print); 2614-350X (online)

Vol.9 No.2 November 2020 Page.644-655

\section{REFFERENCE}

Aneshansley, P., Baffaro, C., Castellano, T., Goins, L., Largaespada, E., Payne, R., \& Stinson, D. (2008). The Performance Appraisal as a Developmental Tool. Public Health Nursing, 24(3).

Apak, S., Gümü, S., Öner, G., \& Gülnihal, H. (2016). Performance Appraisal and a field study. 229, $104-114$. https://doi.org/10.1016/j.sbspro.2016.07.119

Apak, S., Gümüş, S., Öner, G., \& Gümüş, H. G. (2016). Performance Appraisal and a Field Study. Procedia-Social and Behavioral Sciences, 229, 104 - 114. https://doi.org/10.1016/j.sbspro.2016.07.119

Bandura, A. (2006). Guide for constructing self-efficacy scales. Self-Efficacy Beliefs of Adolescents, 307 - 337. https://doi.org/10.1017/CBO9781107415324.004

Carter, W. R., Nesbit, P. L., Badham, R. J., Parker, S. K., \& Sung, L. K. (2018). The effects of employee engagement and self-efficacy on job performance: a longitudinal field study. International Journal of Human Resource Management, 29(17), 2483 2502. https://doi.org/10.1080/09585192.2016.1244096

Chairina, R. R. L., Sularso, R. A., Tobing, D. S. K., \& Irawan, B. (2019). Determinants of nurse performance in accredited Indonesian private hospitals. Problems and Perspectives in Management, 17(1), 163 - 175. HTTPS://doi.org/10.21511/ppm.17 (1). 2019.15

De Simone, S., Planta, A., \& Cicotto, G. (2018). The role of job satisfaction, work engagement, self-efficacy and agentic capacities on nurses ' turnover intention and patient satisfaction. Applied Nursing Research, 39(October 2017), 130 - 140. https://doi.org/10.1016/j.apnr.2017.11.004

Dusterhoff, C., Cunningham, J. B., \& MacGregor, J. N. (2014). The Effects of Performance Rating, Leader - Member Exchange, Perceived Utility, and Organizational Justice on Performance Appraisal Satisfaction: Applying a Moral Judgment Perspective. Journal of Business Ethics, 119(2), 265 - 273. Https://doi.org/10.1007/s10551-013-1634-1

Gesme, D. H., \& Wiseman, M. (2011). Performance Appraisal: A Tool for Practice Improvement. Journal of Oncology Practice, 7(2), 131 - 134. https://doi.org/10.1200/jop.2010.000214

Jeffs, L., Beswick, S., Lo, J., Lai, Y., Chhun, A., \& Campbell, H. (2014). Insights from staff nurses and managers on unit-specific nursing performance dashboards: A qualitative study. BMJ Quality and Safety, 23(12), 1001 - 1006. https://doi.org/10.1136/bmjqs-2013-002595

Kahya, E. (2018). Applicable Performance Criteria to Evaluate Clinical Nurses. 21(2), $289-304$

Kahya, E., \& Oral, N. (2018). Measurement of clinical nurse performance: Developing a tool including contextual items. Journal of Nursing Education and Practice, 8(6), 112. https://doi.org/10.5430/jnep.v8n6p112

Kalb, K. B., Cherry, N. M., Kauzloric, J., Brender, A., Green, K., Miyagawa, L. A., \& Shinoda-Mettler, A. (2006). A Competency-based approach to public health nursing performance appraisal. Public Health Nursing, 23(2), 115 - 138. https://doi.org/10.1111/j.1525-1446.2006.230204.x

Kurniawan, M. H., Hariyati, R. T. S., \& Afifah, E. (2019). The relationship between caring preceptor, self-efficacy, job satisfaction, and new nurse performance. Enfermeria Clinica, 29, 464 - 470. https://doi.org/10.1016/j.enfcli.2019.04.069

Lippke, S. (2017). Encyclopedia of Personality and Individual Differences. Encyclopedia 


\section{STRADA Jurnal Ilmiah Kesehatan}

DOI: $10.30994 /$ sjik.v9i2.349

ISSN: 2252-3847 (print); 2614-350X (online)

Vol.9 No.2 November 2020 Page.644-655

of Personality and Individual Differences, 1 - 6. Https://doi.org/10.1007/978-3-31928099-8

Mangi, N. G., Ter Goon, D., \& Yako, E. M. (2019). Self-Efficacy and Clinical Performance of Nurses Initiated and Management of Antiretroviral Therapy: Narrative Review. The Open Public Health Journal, 12(1), 86 - 93. https://doi.org/10.2174/1874944501912010086

Menkes. (2019a). No Title. Indonesian Minister of Health Regulation No. 1 of 2019 on guidelines for Employee Achievement Assessment in Ministry of Health's Environment.

Menkes. (2019b). Indonesian Ministry of Health Regulation No. 1 of 2019 on guidelines for Employee Achievement Assessment in Ministry of Health.

Negussie, N., \& Berehe, C. (2016). Factors affecting performance of public hospital nurses in Addis Ababa region, Ethiopia. Journal of the Egyptian Public Health Association, 91(1), 26 - 30. https://doi.org/10.1097/01.EPX.0000480931.63648.9b

Nikpeyma, N., Saeedi, Z. A., AZARGASHB, E., \& Majd, H. A. (2014). Problems of Clinical Nurse Performance Appraisal System: A Qualitative Study. Asian Nursing Research, 8(1), 15 - 22. https://doi.org/10.1016/j.anr.2013.11.003

Sabitah, N., \& Susilo, H. (2017). IMPLEMENTATION of the METHOD of PERFORMANCE ASSESSMENT 360 DEGREE FEEDBACK TO MEASURE the SOFT COMPETENCE EMPLOYEES (Study of PT Petrokimia Gresik). Journal of Business Administration S1 of Brawijaya University, 47(1), 56 - 62.

Sebayang, S. (2018). Effect of Self Esteem and Self Efficacy of Employee Performance Case Study at PT. Finnet Indonesia. Journal of Management, 60(1), 335 - 345.

Vafaee Najar, A., Pooya, A., Alizadeh Zoeram, A., \& Emrouznejad, A. (2018). Assessing the Relative Performance of Nurses Using Data Envelopment Analysis Matrix (DEAM). Journal of Medical Systems, 42(7). Https://doi.org/10.1007/s10916-0180974-X 